\title{
Islamic Teacher Competency in Madrasah
}

\author{
Undang Burhanudin, Nurhamzah Nurhamzah, Saepudin Rahmatullah, and Jamaludin Jamaludin \\ Teacher Training Faculty \\ State Islamic University of Sunan Gunung Djati \\ Bandung, Indonesia \\ nurhamzah@uinsgd.ac.id
}

\begin{abstract}
The subject of Islamic Religious Education in madrasah is a field of study which has some contents, such as; aqidah akhlak, al quran hadith, fiqih (jurisprudence), and history of Islamic culture. The main problem faced in madrasah today is still low competence of Islamic religious education teachers. One of ways to improve the teacher competences is by professional improvement programs through teacher professional education program. However, the impact of teacher professional education programs on teacher competency improvement has not been widely reported, so it is need to identify the effectiveness of the program. This study used naturalistic inquiry method. The results of the research showed that the teacher's professional education program has an impact on the improvement of teacher competence. It is showed by the average score of pedagogic competence of teachers on the average $80 \%$, while the value of the courses obtained by each participant. In the major of al quran hadith, the average value has $81 \%$, the value of the major of moral subject (aqidah akhlak) has $77 \%$, and the value of the PGMI major has $78 \%$.
\end{abstract}

Keywords - Teacher competency; Islamic teacher; Islamic Boarding School (madrasah); al quran Islamic tradition (hadith); moral value (aqidah akhlak); Islamic Jurisprudence (Fiqih)

\section{INTRODUCTION}

The quality of teachers in Indonesia should be a common concern, because according to Mushollin, some studies reported that teacher quality in Indonesia is still questionable [1]. In addition, it is caused by teacher's educational background which is not linear and other facts show that $62 \%$ of teachers who are able to answer the problem of early competence test for teachers follow the program of teacher professional education. Meanwhile, students said that unprofessional Islamic religious education in presenting subjects because they found their difficulties in developing material [2] [3]. In previous teacher's professional development program, Saefudin AM outlined that the inherent competence of a religious teacher consists of the ability to know something needs to be thought and understand all subjects which is thought[4].

In Yustiani's researching, it has a difference competence between certified Islamic religious education teachers and noncertified Islamic religious education teachers, but there is no difference competency based on employment status and employment [5]. The results of the study, it is suggested to explore the Islamic religious education's competence on the pedagogic aspect. Researching on the competence of certified and uncertified religious teachers has been widely reported, but there has been no tracing of Islamic religious education teacher competences following the professional teacher education program. Based on the above description, it is necessary to study regarding with teacher competence on pedagogic aspects that follow the professional teacher education program.

\section{LITERATURE REVIEW}

Teacher competencies as referred in 8 article of Law Number 14 in 2005 regarding with Teachers and Lecturers have pedagogical, personality, social and professional competence which have been gained by professional education.

\section{A. Pedagogical Competence}

In the National Education Standards, the elucidation of 28 article in paragraph (3) at point a stated that: Pedagogical competence is the ability to manage students' learning regarding with their understanding on students, design and implementation of learning, evaluation of learning outcomes, and development of students to actualize the their various potentials.

\section{B. Teacher Professional Education}

Based on Law Number 14 in 2005 regarding with Professional Teachers and Lecturers, it is a work or activity undertaken by a person and a source of living income that requires expertise, skill or skill that integrate with certain quality standards or norms and requires professional education.

Thus Professional Teacher Education is a higher education after the undergraduate program that prepares learners to have a job with special skill requirements. Professional Teacher Education Program in Position which is called as Teacher Professional Education Program (PPG) is an educational program that integrates the presentation of workshop materials and field practices that are held to prepare teachers to master the competence of teachers in full accordance with National Education Standards so as to obtain educator certificate.

\section{METHOD}

This study used qualitative approach with descriptive analytic method. Qualitative research is an approach in conducting research-oriented phenomena or symptoms of a nature (naturalistic inquiry) [6]. Primary data in this research is data about information improvement of the competence of 
Islamic religious education teacher through teacher professional education. The subject of the study is Islamic religious education teachers in West java who follow the professional education program as many as 89 teachers.

\section{RESUlts AND Discussion}

The results obtained from this questionnaire research after being processed in the form of qualitative, which describes the achievement of the competence of Islamic religious education teacher in Madrasah are as follows:

\section{A. Analysis of making Lesson Plan (RPP) in Teaching and Learning Process}

The first Question is directed to the fulfillment of the RPP before entering the class. From the data that can be through the questionnaire it turns out that before they follow the teacher profession development program through Teacher Profession Education (TPE/PPG) majority of them sometimes make Lesson Plan (RPP), even there are some teachers do not make lesson plan (RPP) before entering class. Then after they follow the professional development program of teachers through Teacher Profession Education (TPE/PPG), the majority always makes the lesson plan before entering the class. From the above description, if it we compare between before and after Teacher Profession Education (TPE/PPG), it has a difference.

The analysis if the majority of them make the lesson plan before entering the classroom, it can be said that the success rate of the competence development program of Islamic religious education teacher through teacher profession education (TPE/PPG) in terms of pedagogic competence with the indicator of making lesson plan (RPP) before entering the class is high, $90 \%$ of them always do it.

The second question is still concerned with the making of the Lesson Plans (RPP). Questions are directed to the consistency of making a lesson plan (RPP) without cheating on someone else's lesson plan (RPP) and not ordering others. From the data that they can turn out after PPG program is always consistent to make their own RPP by not cheating on RPP other people and not send others. As for before they follow their PPG program often in making RPP often see and cheat other people's lesson plan (RPP), and sometimes send someone else or download from the internet, without bother making their own lesson plan (RPP).

The analysis of the teacher's statement in making the lesson plan (RPP) has a high consistency without cheating other people's RPP and does not ask others, it can be said that the success rate of teacher competence development program of Islamic religious education through teacher profession education (TPE/PPG) in terms of pedagogic competence with consistency indicator of lesson plan (RPP) making they are always consistent and independent, so it can be said high, $85 \%$ of them always do so.

Then question number three is still concerned with the making of the Lesson Plan (RPP). Questions are directed at making the Lesson Plan (RPP) by taking into account the methods, media used, and available infrastructure. From the data that they can turn out after PPG program is always in making Lesson Plan (RPP) always see the methods and media that will be used, and facilities available infrastructure in teaching and learning process. Before they join the teacher profession education (TPE/PPG) program, they often do not pay attention to the method, the media to be used and the facilities available in the learning process.

Analysis of teacher's statement in making lesson plan (RPP) which always see the method, media to be used and infrastructure facilities in teaching and learning process, it can be said that the success rate of teacher competence development program of Islamic religious education through teacher profession education (TPE/PPG) in terms of pedagogic competence to with indicator of making lesson plan (RPP) by paying attention, the media to be used and facilities in teaching and learning process, they always pay attention to these three things, so the success rate can be said high, $87 \%$ they always do that.

The fourth question is directed to preparing the lesson plan (RPP) by first designing the syllabus. From the data that can be through the questionnaire it turns out that before they follow the program of professional development of teachers through PPG majority of them sometimes make lesson plan (RPP) without compile syllabi firstly. Then after they follow the program of professional development of teachers through teacher profession education (TPE/PPG), the majority always makes the lesson plan (RPP) by preparing the syllabi firstly. From the above description when compared between before and after teacher profession education (TPE/PPG) there was a difference.

Analysis if the majority of them make the lesson before entering the classroom, it can be said that the success rate of the competence development program of Islamic religious education teacher through teacher profession education (TPE/PPG) in terms of pedagogic competence with RPP making indicator by preparing the syllabus is they implement it, thus the success rate is quite high, 78\% always do it.

\section{B. Analysis of the implementation of learning management in teaching and learning process}

The fifth, six and seventh Questions are directed to the implementation of learning management by making learning tools in the form of teaching materials, student worksheets (LKS) and teaching resources. From the data that can be through questionnaires in the management of learning in the class it turns out that they prior to join the professional development program teachers through teacher profession education (TPE/PPG) majority of them sometimes make learning tools in the form of teaching materials, student worksheets (LKS) and teaching resources. Then after they follow the professional development program of teachers through teacher profession education (TPE/PPG), the majority always makes learning tools in the form of teaching materials, student worksheets (LKS) and teaching resources. From the above description when compared between before and after teacher profession education (TPE/PPG) there was a difference.

Analysis if the majority of them make learning tools in the form of teaching materials, student worksheets (LKS) and 
teaching resources, it can be said that the success rate of the competence development program of Islamic religious education teachers through teacher profession education (TPE/PPG) in terms of pedagogic competence with such indicators, said the success rate is high, $82 \%$ they always implement it.

\section{Analysis of the use of learning media in teaching and learning process}

The eight Question is directed at the use of instructional media when teachers teach. From the data it can be concluded that the majority of respondents after the teacher profession education (TPE/PPG) in the learning process always use the learning media. As for prior teacher profession education (TPE/PPG), they generally occasionally use instructional media sometimes also do not use instructional media.

Thus, if they always use the learning media after following the professional development program of teachers through the teacher profession education (TPE/PPG), then the success rate of teacher competence development program through teacher profession education (TPE/PPG) of pedagogic competence with indicator using the learning media during the teaching and learning process they turn it out, thus the success rate is high, $83 \%$ of them always use the learning media.

The ninth Question is directed to the implementation of PBM using the learning media that is in the class and made itself adjusted with the teaching materials. From the data it can be concluded that the majority of respondents after the teacher profession education (TPE/PPG) in the teaching and learning process often use the learning media that exist in the class and made themselves adjusted with the teaching materials. As for prior teacher profession education (TPE/PPG), they generally occasionally use instructional media in the classroom sometimes also do not use instructional media and they do not create their own media generally.

Thus, if they always use the learning media available in the classroom and made themselves adjusted with the teaching materials after following the professional development program of teachers generally, the success rate of teacher competence development program through teacher profession education (TPE/PPG) in terms of pedagogic competence with indicators using learning media that exist in the class and made themselves adjusted to the teaching materials that exist in the classroom and made themselves adjusted with teaching materials when the process of teaching and learning they did it. Thus the success rate in this case is high, $83 \%$ of them always use it.

The tenth Question is directed to the implementation of PBM using ICT-based learning media. From the data it can be concluded that the majority of respondents after the teacher profession education (TPE/PPG) in teaching and learning process sometimes use ICT-free learning media. As for before the teacher profession education (TPE/PPG), generally they are rare and some even never use ICT-based learning media in teaching and learning process.

Thus, if the majority of them sometimes even there some often use ICT-based learning media after following the professional development program of teachers through generally, then the success rate of the competence development program of Islamic religious education teacher through teacher profession education (TPE/PPG) in terms of pedagogic competence with indicators using ICT-based learning media during the teaching and learning process turned out to do it, although sometimes, the success rate in this case is quite high, $75 \%$ of them always use it.

\section{Analysis of the use of learning methods in teaching and learning process}

The eleventh Question is directed to the implementation of PBM using the method of learning. From the data it can be concluded that the majority of respondents after the teacher profession education (TPE/PPG) in the learning process always use the method of learning. As for prior teacher profession education (TPE/PPG), generally they are they are often even some who sometimes use learning methods in teaching and learning process.

Thus, if the majority of them always use the learning method after following the professional development program of teachers through the teacher profession education (TPE/PPG), then the success rate of teacher competence development program through teacher profession education (TPE/PPG) in terms of pedagogic competence with indicators using the method of learning when the process of teaching and learning turned out they always do it, then the success rate is quite high, $78 \%$ they always use it.

The twelve question is directed at the implementation of PBM using learning methods tailored to the teaching materials. From the data it can be concluded that the majority of respondents after the teacher profession education (TPE/PPG) in the learning process always use the method of learning tailored to the teaching materials. As before the teacher profession education (TPE/PPG), generally they often use the method of learning tailored to the teaching materials in the learning process even some of them sometimes use the method of learning tailored to the teaching materials in the learning process.

Thus, if the majority of them always use the learning method adapted to the teaching materials after following the professional teacher development program through the teacher profession education (TPE/PPG), then the success rate of Islamic religious education of teacher development program through teacher profession education (TPE/PPG) in terms of pedagogic competence with indicators using appropriate learning method with teaching materials during the learning process it turns out they always implement it, then the success rate is high, $85 \%$ they always use it.

The thirteenth Question is directed at the implementation of PBM using contextual learning methods. From the data it can be concluded that the majority of respondents after teacher profession education (TPE/PPG) in teaching and learning process often use contextual learning method. As before the teacher profession education (TPE/PPG), they in general sometimes even some who never use the method of contextual learning in teaching and learning process. 
Thus, if the majority of them always use the contextual learning methods after participating in the competence development program of Islamic religious education teacher through teacher profession education (TPE/PPG), the success rate of the competence development program of Islamic religious education teacher through teacher profession education (TPE/PPG) in terms of pedagogic competence with indicators using contextual learning method when it occurs teaching and learning process they always implement it, then the success rate is high, $80 \%$ they always use it.

\section{E. Analysis of the implementation of learning evaluation in teaching and learning process}

Question number fourteen is directed at the implementation of the PBM conducting the learning evaluation. From the data it can be concluded that the majority of respondents after the teacher profession education (TPE/PPG) in teaching and learning process always carry out the evaluation of learning. Whereas before the teacher profession education (TPE/PPG), they generally sometimes even have never implemented a learning evaluation after the teaching and learning process.

Thus, if the majority of them always carry out the evaluation of learning, after following the program of teacher competence development of Islamic religious education teachers through teacher profession education (TPE/PPG), then the success rate of the competence development program of Islamic religious education teacher through teacher profession education (TPE/PPG)in terms of pedagogic competence with indicators performing evaluation of learning after the learning process taught that they always do it, then the success rate can be said high, $90 \%$ they always implement it.

The sixteenth Question is directed at the implementation of the PBM conducting the evaluation of learning in the form of pre-test and post test. From the data it can be concluded that the majority of respondents after the teacher profession education (TPE/PPG) in teaching and learning process always carry out the evaluation of learning in the form of pre-test and post test. Whereas before the teacher profession education (TPE/PPG), generally they sometimes have never conducted a learning evaluation in the form of pre-test and post test after the teaching and learning process.

Thus, if the majority of them always carry out the evaluation of learning in the form of pre-test and post test, after following the professional development program of teachers through teacher profession education (TPE/PPG), the success rate of the competence development program of Islamic religious education teacher through teacher profession education (TPE/PPG)in terms of pedagogic competence with indicator evaluation of learning in the form of pre-test and post test after the teaching and learning process they always implement it, then the success rate can be said high, $85 \%$ they always implement it.

Teacher Professional Education has been trying to improve the competence of teachers in accordance with the field of knowledge. The field of science for the teachers of the Qur'an hadith, of course, given the curriculum spread in a number of courses in accordance with the field of study. The science given to the teachers of the Qur'an hadith in principle is divided into two parts. First, the deepening of teaching materials related to the Qur'an hadith. This course is a reinforcement course for professional competence. Second, the deepening of the methodology of learning of the Qur'an hadith, such as the method of learning the Qur'an of Hadith, the media of AlQuran Hadith, the evaluation of Al-Qur'an Hadith and so on. This course is a course for strengthening pedagogic competence.

From the result of value document and observation data, the success rate of Professional Teacher Education which is in accordance with the specific purpose of improving teachers in the field of science, it turns out that teachers of Islamic religious education who follow the Teacher Professional Education. From both types of competence are pedagogic and professional, of each course, the value of satisfying the average of the majors of the Qur'an hadith is the value of 81. By considering such a value, it seems that the success rate of Teacher Professional Education has been seen from the achievement of this goal is very high. Likewise for the majors Aqidah-Akhlak (moral value) and majors Education Teachers Madrasah Ibtidaiyah. The average score for the moral value (aqidah akhlaq) is $77 \%$ and for the value of the Madrasah Ibtidaiyah Teacher Education is $78 \%$. By looking at these two values it seems that the success rate of Professional Teacher Education seen from the objective of improving the competence according to the field of knowledge is high.

\section{CONCLUSION}

Pedagogy competence of Islamic religious education teachers consisting of making lesson plan (RPP), learning management, media usage and method, and implementation of learning evaluation showed a significant increase after following teacher education program are more than $80 \%$. The competency integrated with the field of science, the average value of subjects obtained by Islamic religious education teachers on moral value (aqidah akhlaq) was $77 \%$ and the value for education of Madrasah Ibtidaiyyah teachers was $78 \%$.

\section{REFERENCE}

[1] Mushollin 2017. Kompetensi Paedagogik Calon Guru Pendidikan Agama Islam (studi tentang kompetensi paedagogik mahasiswa jurusan tarbiyah program studi Pendidikan Agama Islam STAIN Pamekasan tahun akademik 2016). Nuansa. Vol. 14 No. 1

[2] Siswanta Jaka 2012. Kompetensi profesional guru pendidikan Agama Islam (PAI) di sekolah umum tingkat SMA/SMK kabupaten magelang. Inferensi Jurnal Penelitian Sosial Keagamaan Vol. 6, No. 2. 349-370

[3] Taruna MM. 2011 Perbedaan Kompetensi Guru Pendidikan Agama Islam (studi kompentensi guru PAI tersertifikasi dan belum tersertifikasi di MTs Kabupaten Banjar Kalimantan Selatan) Jurnal "Analisa" Volume XVIII, No. 02

[4] AM, Saefuddin. 1990. Desekularisasi Pemikiran Landasan Islami. Bandung: Mizan

[5] Yustiani S 2014. Kompetensi guru Pendidikan Agama Islam pada Madrasah Tsanawiyah di kota Mataram Nusa Tenggara Barat. Jurnal "Analisa" Volume 21 Nomor 01 143-154 Balai Penelitian dan Pengembangan Agama Semarang

[6] Yaya Suryana, Tedi Priatna, 2008 Metode Penelitian Pendidikan. Bandung: Tsabita, 75. 